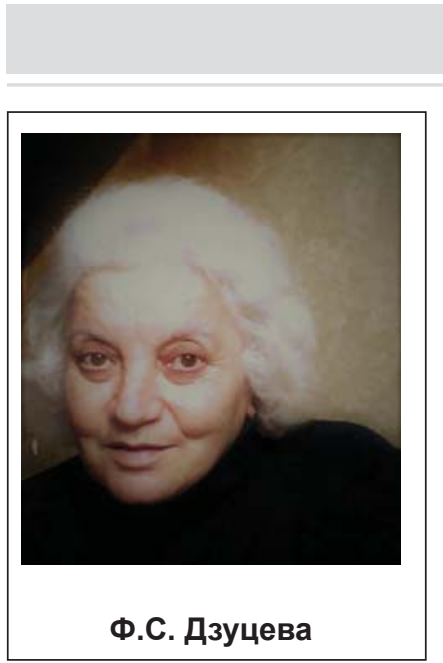

Предлагаемые ниже записи представляет собой то, что принято называть полевым материалом, предназначенным для толкования учеными, специализирующимися в соответствующей области знания, а автор выступает лишь как транслятор информации, посредник между информантом и возможным будущим исследователем описываемого феномена.

Еще подростком меня заинтересовали некоторые непонятные и на первый взгляд совершенно нелогичные во второй половине $\mathrm{XX}$ века особенности в свадебном обряде, которые, тем не менее, неукоснительно соблюдались всеми моими односельчанами и родственниками осетинской национальности, в основном выходцами из Даргавского, Куртатинского и Алагирского ущелий. Обратившись к старшим, я услышала нижеследующее - достаточно, как мне кажется, нетривиальное, малохарактерное для нашей этнографии - разъяснение некоторых «процедур».

Я решила сохранить в возможно полной мере аутентичность информации, поэтому она оформлена в виде своеобразного, внешне слегка стилизованного интервью (со следами оставшихся в моей памяти некоторых фрормулировок) с теми пожилыми соседями, которые с энтузиазмом и благожелательностью, неторопливо и напевно, на великолепном осетинском языке ответили на мои вопросы. Никого из них уже давно нет в живых, а потому цель этой статьи состоит не только в том, чтобы предложить исследователям дополнительный материал, но и, не в последнюю очередь, в том, чтобы отдать дань благодарной памяти всем, кто, как сокровище, сберег в душе и передал младшим бесценное знание, накопленное этносом за долгую историю, - знание, которое определяет его самосознание.

Ф. Д3.:

- Почему у осетин принято не давать согласие на брак девушки, пока послы («минæвæрттæ») жениха хотя бы трижды не «постучатся в дом» (в переносном смысле: «придут просить за жениха») предполагаемой невесты? Ведь если девушка уже обмолвилась, что в ее семью могут пожаловать «гости» от такой-то конкретной фрамилии (в данном контексте эвфемизм, означающий, что придут сваты), это должно означать, что парень и девушка уже приняли решение пожениться. К чему тогда это лицемерие?

Алдатова Люба (Елдадтаты Любæ):

- Это очень древний и очень важный обычай, соблюдение которого совершенно необходимо для блага обоих молодых людей, а для девушки особенно. Время между переговорами сторон предоставляет возможность семьям и невесты, и жениха не только лучше подготовиться к одному из самых важных событий в жизни женщины и мужчины, но и больше разузнать друг о друге, оценить достоинства и недостатки. В наше время женщина выходила замуж единожды, и следовало предусмотреть все возможное, чтобы она была счастлива в браке.

Пухова Дзыкки (Пухаты Дзыкъи):

- Не стоит забывать и о том, что девушка, будущая невеста, у осетин всегда почиталась как высшая ценность семьи.

Ф. Д3.:

- Это из-за калыма, который наши предки мужского пола платили родителям невесты?

Пухова Дзыкки:

- Отнюдь! Сейчас многие недалекие люди так думают, но у наших предков ирæд (калым) имел совершенно другой смысл. Еще на моей памяти в нашем Даргавском ущелье жених не должен был предлагать в качестве калыма то, что он сам не раздобыл, не создал или не заработал. Способность уплатить калым характеризовала жениха как человека, могущего самостоятельно прокормить и должным образом содержать се-

“ Дзуцева Фатима Сафарбековна - к. ф. н., доцент кафедры английского языка факультета иностранных языков СевероОсетинского государственного университета им. К.Л. Хетагурова, Владикавказ (lamardoinag@mail.ru). 
мью. Имей в виду, что семья невесты нередко (по крайней мере, на моей памяти) отдавала скот, оружие, или другое имущество, предъявленное в качестве калыма, молодым, а не оставляла его себе. Бывали, конечно, и некоторые недостойные люди («хицæн æнæгъдау адæймæгтæ»), которые использовали калым для собственного обогащения, но мы не будем помнить их имена!

Ф. Д3.:

- А почему, когда невеста со своей свитой уже отправилась в дом жениха, последний с друзьями устремляется в дом невесты, а не спешит к своей молодой жене, не празднует такое счастливое событие в родном доме? При этом место жениха на свадьбе занимает его друг («къухылхæцæг»)?

Дзуцева Вера (Дзуццаты Верка):

- Да это же самое главное, что должно соблюдаться всеми. Надо понимать, что къухылхæцæг не просто друг жениха, а жених по доверенности кандидатуру которого принимают после долгого и тщательного обсуждения его в смысле порядочности, благонадежности и «сæрæндзинад» (свойство характера, сочетающего в себе самые разные способности, гарантирующие успешное выполнение любой поставленной задачи. Дз.). На свадьбе он от имени жениха выполняет множество всяких функций. Самого жениха, будущего мужа, не подпускают близко к невесте до поры до времени, во избежание нежелательных последствий для репутации невесты при возможных осложнениях.

Ф. Д3.:

- О каких осложнениях может идти речь, и каким образом общение с женихом может навредить репутации невесты, если свадьба уже в самом разгаре?

\section{Алдатова Люба:}

- Не всякая невеста, даже уже прибывшая в дом жениха, выберет стать женой, и очень важно, чтобы ее неприкосновенность не была нарушена.

Ф. Д3.:

- Как это возможно?

Алдатова Люба:

- Дело в том, что невеста не только выходит замуж за данного конкретного мужчину, но и несет фрарн (осетинская реалия, обозначающая все высшие материальные и духовные ценности. - Ф.Дз.) своей семьи в его семью, берет на себя ответственность продолжать лучшие ее (новой семьи) традиции, поддерживая в ней отношения любви, заботы и уважения. Если семья жениха не приняла ее, держательницу и частицу фарна мира («дунейы фарны хай»), достойным образом, если невеста узнала о чем-либо, порочащем жениха, и поняла, что не готова посвятить свою жизнь этому мужчине и этой семье, она может вернуться в дом своих родителей и, со временем, выйти замуж за кого-либо другого, в какую-либо другую семью, которую она и ее семья сочтут более достойной.

Ф. Д3.:

- А много ли было таких случаев?

Цахилова Хадизат (Цъæхилты Хадизæт):

- Вообще, это было очень редко, но я помню, моя двоюродная тетя отказалась остаться в доме жениха. Я не хочу называть имя отвергнутого жениха, ибо это не делает чести всей его фамилии, но скандал был такой, что несостоявшийся жених не мог жениться еще несколько лет, пока наконец не привез себе жену с Юга, где ни о нем, ни о его семье никто не знал.

Ф. Д3.:

- Неужели после того как девушка побывала в доме жениха, кто-нибудь еще готов был на ней жениться?

Пухова Дзыкки:

- Возвращение девушки в родительский дом по ее собственному желанию было, конечно, событием крайне нежелательным и свидетельствовало о том, что семья невесты не изучила все обстоятельства жизни жениха и его семьи, но само по себе это ни в коей мере не снижало авторитет девушки в глазах других потенциальных женихов. Для этого и существовали обряды и процедуры, которые должным образом гарантировали как неприкосновенность самой девушки, так и свидетельства того, что она не утратила целомудрия и может составить счастье другого мужчины.

Ты, наверное, заметила, что осетинская свадьба состоит, как минимум, из двух этапов. На первом этапе происходят две свадьбы, со всеми ритуалами выведения девушки из родительского дома и введения ее в дом жениха. При этом, как мы уже установили, сам жених со свитой (члены которой одновременно могут выступить в качестве свидетелей) должен находиться вдали от того места, где выполняются обряды с участием невесты. Обычно, когда невеста уже приближается к дому жениха, он отправляется с визитом в дом родителей невесты («сиахсы цыд»). Это, если хочешь, своего рода первая линия обороны, гарантирующая незапятнанность репутации девушки. Вторую линию обороны обеспечивает свита невесты, в которую входят родственники, соседи и друзья семьи невесты, которые сопровождают невесту и непрерывно находятся с нею в доме жениха некоторое время, до второго, как правило, заключительного этапа свадебного обряда. При этом девушка из свиты невесты ночует с невестой в одной комнате, а мужчина из свиты невесты укладывается на ночь снаружи у двери в комнату невесты, в качестве охраны.

Затем наступает второй, не менее важный этап заключения брака у осетин. Он состоит в 
том, что через некоторое время (раньше это могло быть несколько дней, или даже недель, в зависимости от того, как далеко друг от друга жили семьи будущих родственников, или от других обстоятельств), в дом жениха отправляется еще одна делегация («хуынхæсджытæ»), официальная миссия которой - доставка в дом жениха приданого невесты («хуынхаст»). Однако, помимо этой официальной цели, хуынхæсджытæ выполняют еще одну важную и тайную миссию: они приватно интересуются у невесты и ее свиты (которая постоянно пребывала подле невесты, оберегая ее как зеницу ока, и одновременно выступая в качестве своеобразных лазутчиков, наблюдающих за тем, что происходит в доме, что говорят соседи и т. д.), сможет ли она прижиться в этом доме, желает ли она в нем остаться.

Ф. Д3.:

- Не потому ли во время свадьбы гости часто в шутку пугают невесту тем, что жених уже не первый раз женат, что он - «Синяя борода», что золовки - оборотни («ус-бирæгътæ»), а свекровь - сущая ведьма («къулбадæг ус»)?

\section{Пухова Дзыкки:}

- Разумеется. Но, как бы ни было, если невеста готова остаться, а свита подтверждает благонадежность семьи жениха, приданое и подарки разгружают, раздают с пожеланиями добра и процветания, после чего они отправляются в обратный путь, оставляя невесту одну в семье жениха.

Ф. Дз.: - Значит, свита невесты и хуынхæсджытæ иногда так многочисленны из-за того, что за невестой все еще сохраняется право отрицательного ответа?

Цахилова Хадизат:
- Именно; ведь может наступить и третий этап брачной церемонии - разрыв отношений, отмена договоренностей. В таком случае семья жениха может попытаться не позволить родственникам невесты забрать ее, и могут понадобиться силы, чтобы защитить священное право женщины на выбор, закрепленное в Æгдау (свод неписанных этических норм. - Ф.Дз.). Поэтому раньше среди свиты невесты были в основном мужчины и не более одной-двух женщин. Сейчас, правда, женщин бывает больше.

\section{Селение Нижнее Камбилеевское (в настоящее время с. Ир) Пригородного района СОАССР (в настоящее время РСО-А), 1968 2.}

Изложенное, на мой взгляд, еще раз (и помимо остального) убеждает в том, что осетинская женщина никогда не была жестко и унизительно ограничена в правах (как об этом писали многие этнографы XIX века). Сообщество считалось с ее интересами, учитывало ее мнение, заботилось о ее благополучии. Действительно, маловероятно, чтобы женщина, находящаяся, по сути, на положении рабыни, была способна родить и воспитать мужчин и женщин с таким достоинством, которым, по описанию подавляющего большинства исследователей, отличались наши предки. Другое дело, что существовало неравенство в отношениях между старшими и младшими женщинами, но подобная иерархия существовала и внутри мужского сообщества.

В более широком смысле данный материал актуален ввиду известной деградации семейнобрачных и половых отношений, которой не избег, к сожалению, и осетинской народ.

\title{
TO THE ISSUE OF THE OSSETIAN MARRIAGE RITE (ETHICAL ASPECTS AND WOMEN'S RIGHTS)
}

\author{
F.S. Dzutseva
}

PhD, Associate Professor. North Ossetian State University named after K.L. Khetagurov. Vladikavkaz. Russia (lamardoinag@mail.ru). 